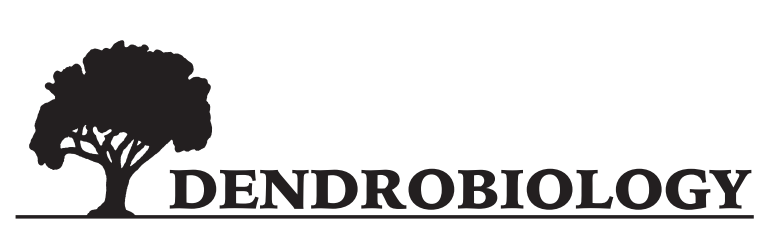

2015, vol. 73, 145-152

http://dx.doi.org/10.12657/denbio.073.015

\author{
Alar Läänelaid, Samuli Helama, Dieter Eckstein
}

\title{
A 434-year tree-ring chronology of spruce (Picea abies) with indications of Estonian precipitation
}

Received: 29 April 2014; Accepted: 2 July 2014

\begin{abstract}
In this study, an Estonian tree-ring network of Norway spruce (Picea abies (L.) H.Karst.), originating from both living trees and dead wood of construction wood, was used for determining the growth variations over the past 350 years (AD 1657-2009). Regional curve standardization was used to remove the non-climatic growth variations from the individual tree-ring series prior to dendroclimatic analyses to focus on the low-frequency (long-term and -period) growth variations. Previously, the chronology has been shown to correlate markedly well with Estonian precipitation history. Here we further detail this dendroclimatic connection. Correlations between the Estonian precipitation and treerings improved systematically with both the number of meteorological stations included and with the documented technical advances in the network of instrumental weather observations. The observed June precipiation explains roughly 20 percent of the tree-ring variance over the period when the network of weather observations is densest (1946-2009). On decadal and longer scales, the June precipitation explains higher portion of treering variance, roughly 50 percent, over the full instrumental era (1866-2009). Comparison with previously published and similarly standardized tree-ring chronology from south-eastern Finland, based on Scots pine tree-rings, showed that the two chronologies exhibit several coinciding periods of ameliorated and deteriorated growth.
\end{abstract}

Additional key words: conifer, dendrochronology, dendroclimatology, drought, regional curve standardization

Addresses: A. Läänelaid, Department of Geography, University of Tartu, Vanemuise St. 46, 51014 Tartu, Estonia

S. Helama, Finnish Forest Research Institute, Northern Unit, PO Box 16, FI-96301 Rovaniemi, Finland, e-mail: samuli.helama@luke.fi

D. Eckstein, Department of Wood Science, University of Hamburg, Leuschnerstrasse 91, D-21031

Hamburg, Germany

\section{Introduction}

Tree rings are versatile indicators of arboreal growth variations (Fritts 1976). Construction of treering chronologies using the samples of standing trees is typically continued by using the dead wood mate- rials. With desire to extend the chronologies back in time, the construction of long tree-ring chronologies is facilitated by using the tree rings of construction timber (e.g. Bartholin and Karlén 1983). That is, the dendrochronological samples originating from old buildings can be cross-dated against the living tree 
chronologies of the same region and species. During the recent years, the number of long tree-ring chronologies around the Baltic Sea has increased (Helama and Lindholm 2003; Linderholm et al. Helama et al. 2009; Koprowski et al. 2012). A feature common to many long chronologies constructed around Baltic Sea is that their representative species is Scots pine (Pinus sylvestris L.) (Bartholin and Karlén 1983; Helama et al. 2009; Koprowski et al. 2012; Läänelaid et al. 2012). By contrast, the main aim of this paper is to estimate the short- and long-term growth variations of Norway spruce (Picea abies (L.) H.Karst.) using a tree-ring network of that species from Estonia. The chronology construction is described using the treering series from living and dead (construction timber) wood materials. Altogether, 678 dated tree-ring series covering the past 434 years were used for the spruce chronology. The modern part of this chronology was previously compared with Estonian climate variables and it was shown that the chronology correlates markedly well with the regional June precipitation variations (Läänelaid and Eckstein 2012). In this study, (1) the tree-ring growth variations were estimated using a dendrochronological method that is known to retain the low-frequency (i.e. long-term and -period) growth fluctuations. Moreover, a more detailed (2) analysis on the described June connection (Läänelaid and Eckstein 2012) was carried out on relevant temporal windows and scales. In addition, (3) the resulting chronology was statistically compared with similarly produced tree-ring chronology of Scots pine from southern Finland (Helama et al. 2009). Since both of these chronologies evidence markedly high correlation to early-summer precipitation, the comparison was expected to pinpoint the large-scale conifer growth anomalies driven by historical regional precipitation variations.

\section{Material and methods}

\section{Tree-ring material}

The tree-ring samples originate from a number of locations in Estonia (Fig. 1). The most common forest site types with spruce as the main tree species in Estonia are Oxalis acetosella - Vaccinium myrtillus site type (11.9\% of the state forest area), Oxalis acetosella forest site type (10.6\%) and Aegopodium podagraria forest site type $(7.2 \%$ of the state forest area) (Laas et al. 2011), while Hepatica forest site type covers $5.5 \%$ of the state forest area (ibid.). Although Vaccinium myrtillus forest site type is one of the most common forest types in Estonia (Lõhmus 2004; Laas et al. 2011), its main tree species is Scots pine and spruce can occur there only as a second species. Our 678 ring-width series of spruce extend from 1576 to 2009. Of them 257 series are from living trees and
421 are from construction timber. In seven sampling sites of the living trees the forest site type was recorded as follows: five sites belong to Hepatica forest site type whereas two sites belong to Vaccinium myrtillus forest site type. As the samples of historical timber originate from roof constructions or walls of old buildings such as stone churches, manor houses and farmhouses, one could assume the forest site types of these timbers belonging to the common forest types of Estonia. Accordingly, the dataset of historical tree-ring series was not sub-regionally divided but was adopted here in its entirety. Tree-ring widths were measured under a light-microscope to the nearest $0.01 \mathrm{~mm}$ to produce tree-ring time-series in computer-aided system. All these series were cross-dated (Fritts 1976) and a computer software (Holmes 1983) was used to discover any possible measurement mistake. The chronology is replicated by at least 11 series since AD 1627 with maximum sample depth reaching 255 series.

\section{Removing non-climate variations}

Because the tree-ring series of individual trees are known to contain non-climatic information, typically in the form of a long-term trend of declining width of annual rings, it is essential to remove (i.e., detrend) this component of the growth variations prior to dendroclimatic analyses. In this study, the regional curve standardization (Briffa et al. 1992) was applied to remove these trends prior to chronology construction and dendroclimatic interpretation. The method was chosen as it is known to preserve more long-term variations in the resulting chronology than many other commonly used methods of chronology construction (Briffa et al. 1992; Esper et al. 2003; Helama et al. 2004). First, each series were aligned according to ring number. An average growth curve was calculated as an arithmetic mean of all available and correspondingly aligned tree-ring width values. This trend was further modeled using the function (Fritts et al. 1969) which can be expressed as

$$
y(x)=j e^{-c x}+m
$$

where $j$ and $m$ determine the extent of the juvenile and mature growth levels, respectively. The coefficient $c$ determines the concavity of the non-linear growth trend. The formula was calculated as a function of tree age $x$. Once the expected growth trend was estimated, the initial measurement series were detrended by extracting the dimensionless tree-ring indices from the expected growth curve by division. The tree-ring chronology was produced by averaging the crossdated (i.e. aligned according to calendar years) series into the mean chronologies using arithmetic mean. 


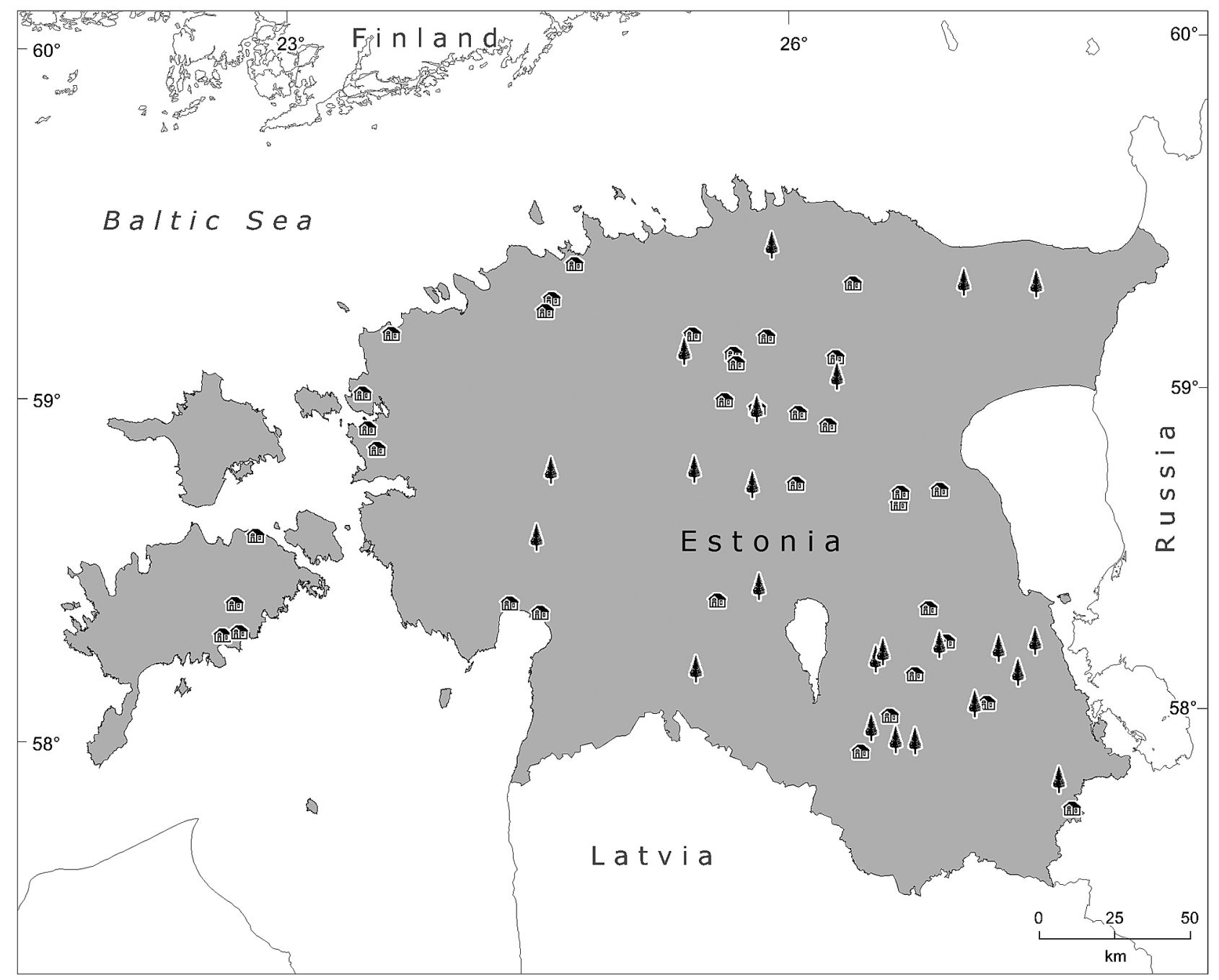

Fig. 1. Location of sample sites of spruce in Estonia. The tree figures depict sample sites of living trees and houses depict sites of construction timber. Several sample sites in one town are shown with a single sign

Moreover, it has been recommended to calculate the expected growth trend of treerings after partitioning the dataset into living and dead wood materials (Esper et al. 2003), or, alternatively, into different classes of fast and slow growing trees (Briffa and Melvin 2011). With these regards, the relative growth rate $(R G R)$ could be assessed "according to the ratio of the radius of each tree divided by the radius of the single, overall-sample RCS curve at the point corresponding to the final age of that tree" (Briffa and Melvin 2011). Here, we follow previously published (Helama et al. 2012) mathematical derivation of the RGR that could be expressed as

$$
R G R=\sum_{a=1}^{n} w_{a} / \sum_{a=1}^{n} \bar{w}_{a}
$$

where is the width of a treering in year in the series possessing tree-rings and is the mean width of all rings in year. We computed $R G R$ separately for each tree. Following these ideas, we partitioned the full dataset of spruce tree-ring width series into four classes: fast ( $R G R$ higher than the mean $R G R$ ) and slow ( $R G R$ lower than the mean $R G R$ ) growing living trees, and series indicating fast and slow growth in the dead wood of construction timber. The partitioning resulted in four different growth curves, all aligned according to the ring number, and modelled using the formula of modified negative exponential curve (Fritts et al. 1969). The series of individual trees were detrended using the division-method, and the tree-ring chronology was averaged from the crossdated series. The variance of the tree-ring chronology was stabilized (Osborn et al. 1997). Expressed Population Signal (EPS) was used as a measure of chronology confidence. The EPS was calculated according to an equation derived previously (Wigley et al. 1984). The years in the chronology when the EPS remained above the limit of 0.85 (Wigley et al. 1984) were accepted for the dendroclimatic comparisons. 


\section{Dendroclimatic analyses}

The monthly series of June precipitation totals were derived from a network of available precipitation series of instrumental observation in Estonia since 1866 (Jaagus 1992). Association between the climate and tree-ring variability was computed using Pearson correlations. To estimate the influence of the historical development of the precipitation network on the strength of the dendroclimatic association, the precipitation-growth correlations were calculated over different periods. Following the previously published description (Jaagus 1992), the history of the network started when the Meteorological Observatory of Tartu University was opened in 1865. The number of stations increased and around the year 1900 the network consisted of over 50 stations whereas there was already roughly 100 stations operating during the 1920s. After 1945 the measurements were made twice a day, and since 1966 four times a day. Moreover, since that year, the wetting of the rainfall gauge had been taken into account (Jaagus 1992; Jaagus et al. 2010). Guided by this information, we calculated the correlations over five periods 1866-2009, 1900-2009, 1920-2009, 1946-2009 and 1966-2009. The tree-ring chronology was also regressed against the instrumental precipitation record and the coefficient of determination $\left(\mathrm{R}^{2}\right)$ was computed over the calibration period and its statistical significance was estimated using a Monte Carlo method (Efron and Tibshirani 1986) as previously described (Macias-Fauria et al. 2012).

\section{Results}

\section{Standardization of the tree-ring series}

Radial growth of Norway spruce exhibited a notable negative trend of exponential shape (Fig. 2a). The average growth near the pith was around $3.0 \mathrm{~mm}$ but at the age of 200 years the rings were around $1 \mathrm{~mm}$. A modified negative exponential function was fitted to the mean growth trend for years with sample replication at least ten series, and the model was subsequently extended over the full length. Classifying the tree-ring series into four classes according to their origin (living forest trees and construction timber of dead wood) and relative growth rate $(R G R)$ further revealed that the spruces of these types showed deviating trends of their age-dependent growth decline. The growth of fast growing trees remained constantly above the overall growth level of slow growing trees. This was evident for both the mean growth decline (Fig. 2b) as well as the parameterized models of growth declines (Fig. 2c). Further inspection of the growth trends revealed that the living spruces appear have notable straighter growth trends, as
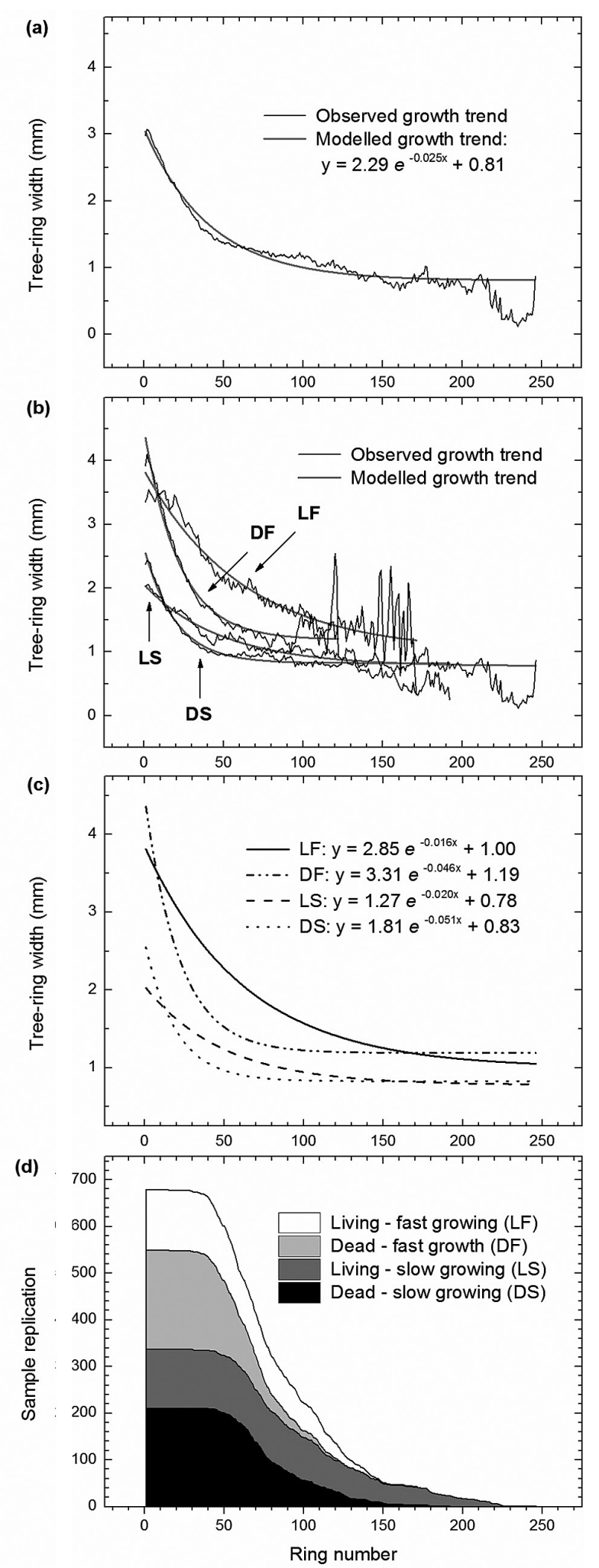

Fig. 2. Mean age-dependent change in the original tree-ring series as a function of ring number. The observed mean growth trends (black line) were modelled using negative exponential functions (grey line) (a). The growth trend was estimated averaging all available tree-ring series in each type of the four tree classes (b). Modelled growth trends were parameterized and compared (c). Sample replication declined as a function of ring number (d) 
indicated by the parameter $c$ ranging between 0.016 and 0.020 in the models, in comparison to the more concave trends of dead spruces with the parameter $c$ ranging between 0.046 and 0.051 (Fig. 2c). Calculating $R G R$ over the five sites from Hepatica forests averaged 1.26 , the $R G R$ s ranging between 1.15 and 1.35 , whereas the mean $R G R$ for tree-ring series from the two sites in Vaccinium myrtillus forests was 0.93 , with site-specific $R G R$ s of 0.58 and 1.27. Clearly, the lower RGR in Vaccinium myrtillus forests resulted from an anomalously low growth rate in one of the sites and it would be premature to conclude that the observed differences in growth rates depend, at least exclusively, on forest type. Guided by the analysis of the growth trends, each individual tree-ring series was standardized using the modelled growth trends of their corresponding tree class. In this process, the tree-ring chronology prior to standardization (Fig. $3 a)$, containing the non-climatic variations inherent to the biology of the tree radial growth, becomes re-calculated as RCS chronology (Fig. 3b). Sample size declines considerably prior to AD 1700 (Fig. 3c). The EPS statistic remained over the pre-determined level of 0.85 for the 353 -year interval covering the period AD 1657-2009.

\section{Historical growth variations}

The new tree-ring chronology exhibited vigorous growth variations on different time scale (Fig. 3 ). The most recent century showed a concentration of positive growth extremes. Half of these growth events occurred between 1903 and 2005. Among the poor growth years, the 17th and 19th centuries became well represented, whereas only a single event (AD 1774) indicated extremely poor growth during the 18th century. The year 1941 showed lowest growth within the 20th century and, in the long term context, the second lowest of all years since the beginning of the chronology. Long-lasting periods with markedly improved growth became obvious at the turn of the 17 th and 18th centuries, during the early decades of the 19th and 20th centuries, as well as during the later part of the 20th century. Periods of low growth levels were observed during the later part of the 17th century, and after the mid-19th century (Fig. 3b).

\section{Detailing the precipitation linkage}

Tree rings correlated systematically better with June precipitation variations when the comparison was done over the years with higher number of available precipitation data. Coefficients of correlations for periods 1866-2009, 1900-2009, 1920-2009, 1946-2009, and 1966-2009 were 0.42, 0.43, 0.44, 0.45 , and 0.48 , respectively. This change was consistent with the historical development of the region-
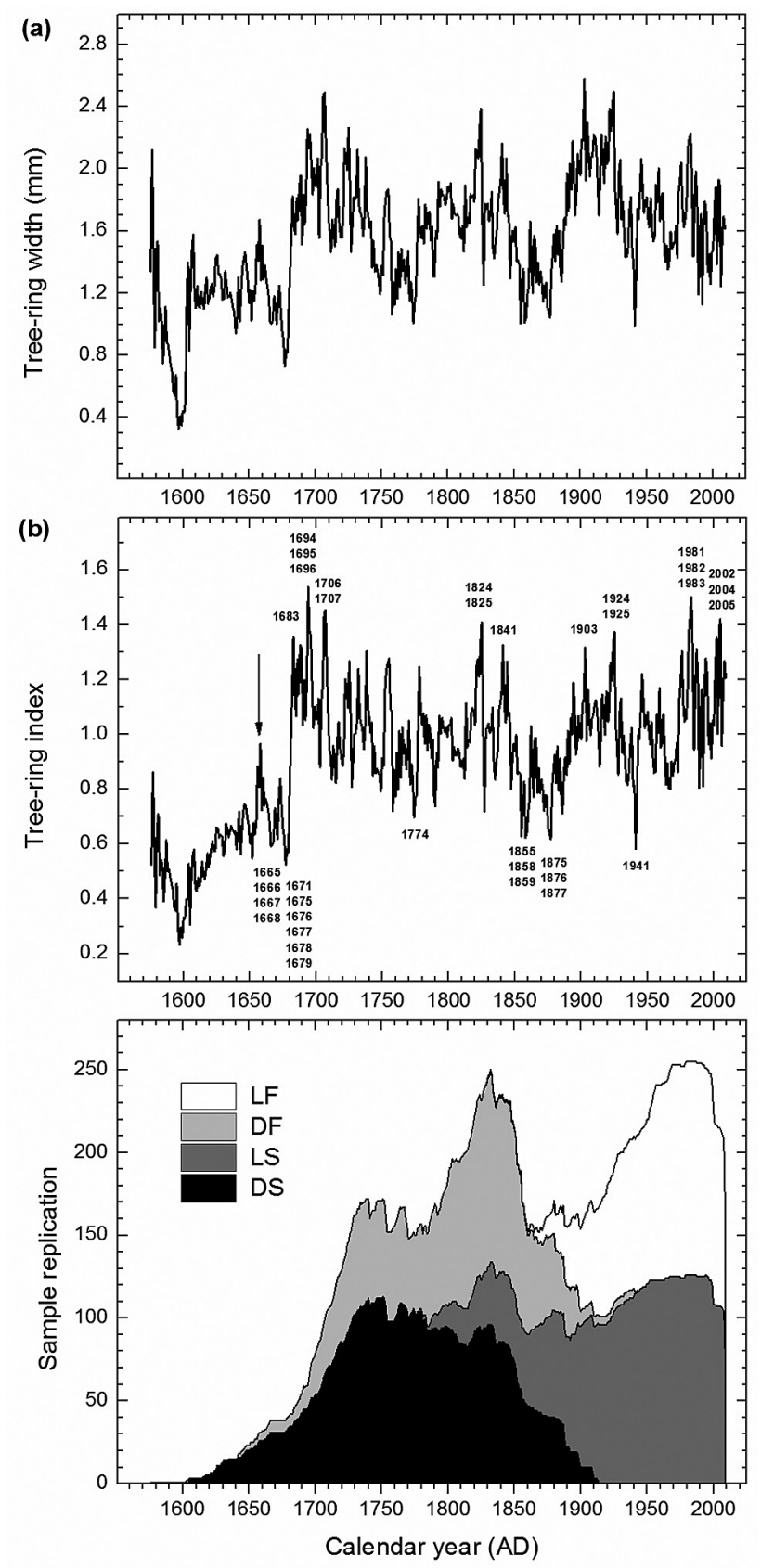

Fig. 3. Tree-ring chronologies of Picea abies in Estonia. The annual growth estimates were computed using the original measurement series without detrending (a), and the RCS implementation, with the downward arrow showing the year of 1657 and the calendar dates indicating the most positive and negative growth years (b). The sample replication as a function of time is shown in relation to the four curve types (see Fig. 2) used in the chronology construction (c)

al precipitation observation network (Jaagus 1992; Jaagus et al. 2010). Since it is also known that the improvement in regionally summarized precipitation data commonly results in more satisfactory results for dendroclimatic transfer functions (Blasing et al. 1981), it was relevant to integrate this information for the selection of calibration period for our precip- 
itation and tree-ring data. Albeit the shortest period (1966-2009) provided best dendroclimatic correlation, we compromised on somewhat longer window length (1946-2009) and carried out the calibration over this period.

Using linear regression, the instrumentally observed June precipitation explained roughly 20 percent of the total variance $\left(\mathrm{R}^{2}=0.201, \mathrm{p}<0.01\right)$ in treering growth in Estonia. The two variables correlated significantly $\left(r^{2}=0.122, p<0.01\right)$ also over the earlier period (1866-1945). We experimented calibrating the decadal and longer scale variations in the treering proxy against the similarly filtered (15-year spline (Cook and Peters 1981)) regional precipitation variations using linear regression (1866-2009). To do so emphasizes the low-frequency variability in the series. A higher correlativity on these scales was exemplified by the increase in the coefficient of determination $\left(\mathrm{R}^{2}=0.508\right)$, evidencing that June precipitation explained more than half of the low-frequency variance in tree-ring growth. Again, the Monte Carlo implementation of significance tests showed that the coefficient of determination was statistically significant $(\mathrm{p}<0.05)$.

\section{Discussion}

\section{Precipitation signals in treerings}

The dendroclimatic signal of June precipitation, found in a previous investigations in Estonia (Pärn and Mandre 2011; Läänelaid and Eckstein 2012), and further detailed through our study, could be compared with the previously published tree-ring analyses in northern Europe, both for its strength and seasonality. Previous studies from Finland and Sweden have emphasized the associations between the precipitation variations and long tree-ring chronologies of pine (Pinus sylvestris). In southern Finland, the tree-ring chronologies have explained for 31-40 percent of the total variance in the instrumentally observed May-June precipitation in the region (Helama and Lindholm 2003; Helama et al. 2009). In east central Sweden, the calibration of tree-ring data against June-August standardized precipitation index accounted for 24 percent of the hydroclimate variance (Linderholm and Molin 2005). Yet another tree-ring model (Jönsson and Nilsson 2009) explained 46 percent of the variation in May-June precipitation in Mideast Sweden. In southeastern Sweden, the treering based June-July precipitation reconstruction accounted for 42 percent of the total variance in the instrumental data (Seftigen et al. 2013). These comparisons with previous studies shows that the target month of our study (June) was actually included in all of these studies, this simply exemplifying the dependence of conifer growth on June precipitation variations in the study region and adjacent areas. Moreover, the explained variance as defined in this study $(20 \%)$ was somewhat comparable albeit at its lower limit with previous studies where the summer precipitation variations have been reconstructed with models accounting roughly between 20 and 45 percent of the total precipitation variance.

Also the long-term precipitation influence was evident in our dendroclimatic data, the June precipitation accounting for roughly 50 percent of that long-term variance. This finding was comparable to results from southern Finland where a high low-frequency correlation was found between early-summer (May-June) precipitation and pine tree-ring growth (Helama et al 2009). Similarly to that reconstruction, our tree-ring study was based on RCS-standardization (Briffa et al. 1992; Briffa and Melvin 2011) as an approach of removing the non-climatic growth variations from the initial tree-ring series. In fact, this method has been proved to preserve the long-term growth variations in the resulting chronology more reliably than a variety of other commonly used methods of chronology construction as demonstrated in several studies for pine (Esper et al. 2003; Helama et al. 2004). Thus, the improved dendroclimatic correlativity on decadeal and longer scales, as found here for spruce in Estonia, implied an additional veracity of the low-frequency precipitation signal in our RCSbased tree-ring chronology.

\section{Broader spatial view}

Estonian tree-ring chronology of spruce could be compared with the recently achieved tree-ring chronology of pine from southern Finland. This is a tree-ring width chronology produced using the RCS method (Helama et al. 2009), similarly to the Estonia spruce chronology of our study. The tree-ring

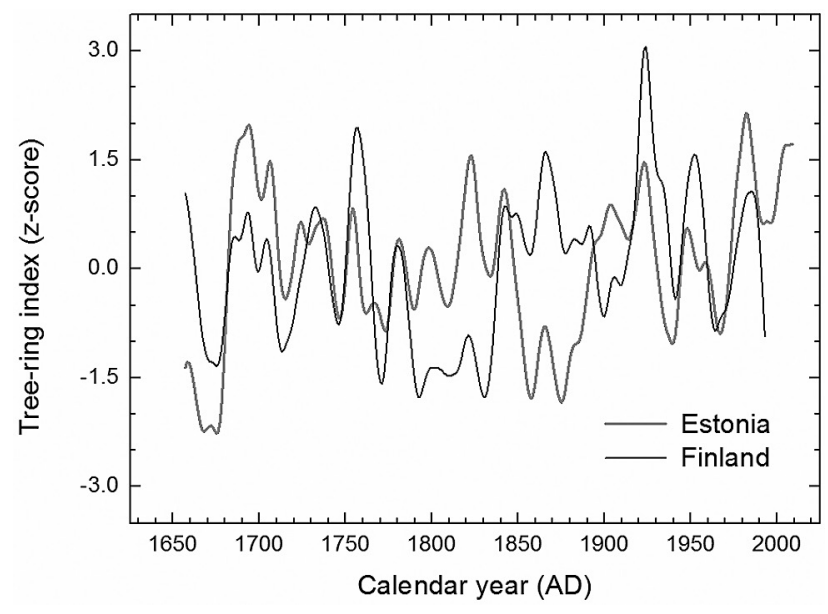

Fig. 4. Comparison of the Estonian and Finnish tree-ring chronologies since 1657 at low frequencies. Z-scores show the growth variations as normalized for the mean of zero and standard deviation of one 
chronologies correlate positively and statistically significantly over the common period (AD 1657-1993) with the correlation coefficient of $0.351(\mathrm{p}<0.001)$. Moreover, the two chronologies were compared for their low-frequency characteristics (Fig. 4). Several common events were detected during which there had clearly been amelioration or deterioration of tree-ring growth within the both chronologies, yet the magnitude of these growth events varied. Moreover, the overall growth conditions appeared deteriorated in Estonia but ameliorated in Finland during the later part of the nineteenth century, with concomitant indication of coinciding growth reversals.

Over the 20th century, both the Estonian and Finnish chronologies exhibited ameliorated growth phases during the 1920s, 1950s and 1980s, with deteriorated spells between these decades. Among the growth events of low growth, the year 1941 was observed as anomalous poor in Estonia, in the context of the tree-ring chronology since AD 1657. Interestingly, the early years of the 1940s came with poor growth also in Finland where these years underwent the most severe drought of the 20th century, this drought lasting the period 1939-1942 (Heino 1994). The same period has been noted as an anomalous drought in the long-term tree-ring context in southern Finland (Helama 2004). Comparison of the two tree-ring records could thus indicate that the response of spruce to this extreme drought was of shorter duration in Estonia, relative to pine growth response in Finland.

\section{Acknowledgements}

We acknowledge the referee comments by two anonymous referees. This study was supported by the project IUT2-16 of Estonia and the Academy of Finland (\#251441).

\section{References}

Bartholin T.S., Karlén W. 1983. Dendrochronology in Lapland. Dendrokronologiska Sällskapet 5: 3-16.

Blasing T.J., Duvick D.N., West D.C. 1981. Dendroclimatic calibration and verification using regionally averaged and single station precipitation data. Tree-Ring Bulletin 41: 37-43.

Briffa K.R., Jones P.D., Bartholin T.S., Eckstein D., Schweingruber H.F., Karlén W., Zetterberg P., Eronen M. 1992. Fennoscandian summers from AD 500: temperature changes on short and long timescales. Climate Dynamics 7: 111-119.

Briffa K.R., Melvin T.M. 2011. A closer look at regional curve standardization of tree-ring records: justification of the need, a warning of some pitfalls, and suggested improvements in its application.
In: Dendroclimatology, progress and prospects. Hughes M.K., Swetnam T.W., Diaz H.F. (eds.). Springer, Dordrecht, pp. 113-145.

Cook E.R., Peters K. 1981. The smoothing spline: A new approach to standardizing forest interior tree-ring width series for dendroclimatic studies. Tree-Ring Bulletin 41: 45-53.

Efron B., Tibshirani R. 1986. Bootstrap Methods for Standard Errors, Confidence Intervals, and Other Measures of Statistical Accuracy. Statistical Science 1: 54-75.

Esper J., Cook E.R., Krusic P.J., Peters K., Schweingruber F.H. 2003. Tests of the RCS method for preserving lowfrequency variability in long treering chronologies. Tree-Ring Research 59: 81-98.

Fritts H.C. 1976. Tree rings and climate. Academic Press, New York.

Fritts H.C., Mosimann J.E., Bottorff C.P. 1969. A revised computer program for standardizing treering series. Tree-Ring Bulletin 29: 15-20.

Heino R. 1994. Climate in Finland during the period of meteorological observations. Finnish Meteorological Institute Contributions 12: 1-209.

Helama S. 2004. Millennia-long tree-ring chronologies as records of climate variability in Finland. Doctoral dissertation. University of Helsinki.

Helama S., Läänelaid A., Raisio J., Tuomenvirta H. 2012. Mortality of urban pines in Helsinki explored using tree rings and climate records. Trees 26: 353-362.

Helama S., Lindholm M. 2003. Droughts and rainfall in south-eastern Finland since AD 874, inferred from Scots pine ring-widths. Boreal Environment Research 8: 171-183.

Helama S., Lindholm M., Timonen M., Eronen M. 2004. Detection of climate signal in dendrochronological data analysis: a comparison of tree-ring standardization methods. Theoretical and Applied Climatology 79: 239-254.

Helama S., Meriläinen J., Tuomenvirta H. 2009. Multicentennial megadrought in northern Europe coincided with a global El Niño-Southern Oscillation drought pattern during the Medieval Climate Anomaly. Geology 37: 175-178.

Holmes R.L. 1983. Computer-assisted quality control in tree-ring dating and measurement. TreeRing Bulletin 3: 69-78.

Jaagus J. 1992. Periodicity of precipitation in Estonia. In: Estonia. Man and Nature. Kaare T., Mardiste H., Punning J.-M. (eds.). The Academy of Sciences of Estonia, Estonian Geographical Society, Tallinn, pp. 43-53.

Jaagus J., Briede A., Rimkus E., Remm K. 2010. Precipitation pattern in the Baltic countries under the influence of large-scale atmospheric circulation and local landscape factors. International Journal of Climatology 30: 705-720. 
Jönsson K., Nilsson C. 2009. Scots Pine (Pinus sylvestris L.) on Shingle Fields: A Dendrochronologic Reconstruction of Early Summer Precipitation in Mideast Sweden. Journal of Climate 22: 47104722.

Koprowski M., Przybylak R., Zielski A., Pospieszyńska A. 2012. Tree rings of Scots pine (Pinus sylvestris L.) as a source of information about past climate in northern Poland. International Journal of Biometeorology 56: 1-10.

Läänelaid A., Eckstein D. 2012. Norway Spruce in Estonia Reflects the Early Summer Weather in its Tree-Ring Widths. Baltic Forestry 18: 196-204.

Läänelaid A., Helama S., Kull A., Timonen M., Jaagus J. 2012. Common growth signal and spatial synchrony of the chronologies of tree-rings from pines in the Baltic Sea region over the last nine centuries. Dendrochronologia 30: 147-155.

Laas E., Uri V., Valgepea M. 2011. Metsamajanduse alused. Tartu Ülikooli kirjastus, Tartu.

Linderholm H.W., Molin T. 2005. Early nineteenth century drought in east central Sweden inferred from dendrochronological and historical archives. Climate Research 29: 63-72.
Lõhmus E. 2004. Eesti metsakasvukohatüübid. Teine, täiendatud trükk. Eesti Loodusfoto, Tartu.

Macias-Fauria M., Grinsted A., Helama S., Holopainen J. 2012. Persistence matters: Estimation of the statistical significance of paleoclimatic reconstruction statistics from autocorrelated time series. Dendrochronologia 30: 179-187.

Osborn T.J., Briffa K.R., Jones P.D. 1997. Adjusting variance for sample-size in tree-ring chronologies and other regional mean timeseries. Dendrochronologia 15: 89-99.

Pärn H., Mandre M. 2011. Dendrochronological analysis of the growth and growth-climate relationships of conifers in the region of alkaline dust deposition. Forest Ecology and Management 262: 88-94.

Seftigen K., Linderholm H.W., Drobyshev I., Niklasson M. 2013. Reconstructed drought variability in southeastern Sweden since the 1650s. International Journal of Climatology 33: 2449-2458.

Wigley T.M.L., Briffa K.R., Jones P.D. 1984. On the average value of correlated time series, with applications in dendroclimatology and hydrometeorology. Journal of Climate and Applied Meteorology 23: 201-213. 